KS. ARKADIUSZ DRZYCIMSKI

Wyższe Seminarium Duchowne w Pelplinie

\title{
PSYCHOLOGIA PASTORALNA JAKO NAUKA POMOCNICZA TEOLOGII PRAKTYCZNEJ
}

Kościół ${ }^{1}$ stanowi źródło zainteresowania wielu dziedzin naukowych, zarówno teologicznych jak i pozateologicznych. Rzeczywistość dotycząca problematyki eklezjalnej jest bardzo bogata. Teologiczna refleksja naukowa może dotyczyć badań o charakterze historycznym, dogmatycznym, fundamentalnym oraz praktycznym. Teologia pastoralna ${ }^{2}$ współpracuje $\mathrm{z}$ dziedzinami pozateologicznymi, które również starają się podejmować badania w ramach mi.in. socjologii i psychologii.

W teologii posoborowej Kościół ujmowany jest jako organiczna jedność, analogiczna do jedności żywego organizmu. „Odznacza się ona w istocie współistnieniem wielorakich powołań i stanów, tajemnic i charyzmatów, i zadań, które choć różne, są w stosunku do siebie komplementarne" (ChL 20). W tej perspektywie teologia po II Soborze Watykańskim prezentuje bardzie integralne, aniżeli wcześniej, spojrzenie na trzy zasadnicze struktury Kościoła: charyzmatyczną, hierarchiczną oraz uniwersalno-lokalną. Zob. A. Czaja, Traktat o Kościele, w: Dogmatyka, Traktat o Maryi, Traktat o Kościele, red. E. Adamiak, A. Czaja, J. Majewski, Wydawnictwo Więź, Warszawa 2006, t. 2, s. 407-408; W. Kasper, Sakrament jedności. Eucharystia i Kościót, thum. R. Zajączkowski, Wydawnictwo Jedność, Kielce 2005, s. 13.

2 Na gruncie teologii pastoralnej jako dyscypliny o charakterze praktycznym trwa dyskusja w sprawie jej nazwy, jej specyficznego charakteru, zasady formalnej teologii pastoralnej i związku z dyscyplinami cząstkowymi oraz stosunku teologii pastoralnej do innych dyscyplin naukowych. Wciąż żywa jest polemika nad związkiem między teorią i praktyką eklezjalną oraz stosunkiem praktycznej działalności Kościoła do działalności w świecie. Teologia pastoralna (zwana dawniej teologią pasterską) ukierunkowuje myślenie o tej dyscyplinie na działalność duchownych, a zdaniem redaktorów Handbuch der Pastoraltheologie, jej przedmiotem jest cała wspólnota Kościoła, czyli lud Boży, a nie tylko hierarchia kościelna. Obecnie wskazuje się na potrzebę pogłębionej inicjatywy formacyjnej w celu określenia istoty, celu, przedmiotu materialnego i formalnego teologii pastoralnej jako teologii praktycznej. W tak rozumianej dyscyplinie naukowej jej przedmiotem badawczym są modele teologiczne, imperatywy i programy działania, w których ustaleniu teologia praktyczna korzysta z teologii systematycznej. Zob. R. Kamiński, Problemy dyskutowane w teologii pastoralnej, ,Roczniki Teologiczne”, t. 48, 2001, z. 6, s. 5-18. 
Do zadań teologii praktycznej możemy zaliczyć m.in. kształtowanie samoświadomości aktualnie działającego Kościoła, która jest konieczna do skutecznego oddziaływania we wspólnocie eklezjalnej. Podejmowane analizy mają mieć charakter teologiczno-pastoralny oraz teologiczno-historyczny, teologiczno-socjologiczny lub teologiczno-psychologiczny. Zróżnicowane metody badawcze służą weryfikowaniu zasadności i skuteczności istniejących form aktywności eklezjalnej. Teologiczna interpretacja określonych zjawisk i procesów zachodzących w Kościele i świecie związana jest z odczytywaniem znaków czasu . A to ma prowadzić do ustalenia konkretnych programów i wskazań pastoralnych, według których powinna przebiegać działalność Kościoła ${ }^{4}$, stosując się do zasady: „Ecclesia in agere". Przywołana zasada pozwala odróżnić teologię pastoralną od eklezjologii, która uprawiana jest $\mathrm{w}$ ramach teologii systematycznej. Teologia pastoralna zajmuje się „Kościołem w działaniu”, jego wymiarem egzystencjalnym i dynamicznym, a więc jego działalnością w świecie, którą definiuje jako działalność społeczno-historyczną i transcendentną

Do specyfiki teologii pastoralnej należy jej praktyczny, jak i normatywny charakter. Zajmuje się ona badaniem rzeczywistości społecznej i indywidualnej, uwzględniając warunki miejsca i czasu danej wspólnoty eklezjalnej. „Skuteczna działalność Kościoła zakłada wiedzę o rzeczywistości społecznej, historycznej, religijno-duszpasterskiej i psychologicznej, czyli znajomość osób i grup ludzi, na które Kościół oddziałuje" ${ }^{\prime 6}$. Jest to również dyscyplina o charakterze normatywnym, gdyż jako jeden z celów stawia sobie wypracowanie norm i zasad, którymi winny się kierować z jednej strony wspólnoty eklezjalne, z drugiej zaś ich reprezentanci w różnych dziedzinach i sferach urzeczywistniania się wspólnoty eklezjalnej. W oparciu o sformułowane normy ustala się imperatywy dla działalności wspólnot eklezjalnych oraz pojedynczych osób $\mathrm{w}$ danym czasie ${ }^{7}$.

W związku ze złożonością przedmiotu istnieją w teologii pastoralnej zróżnicowane sposoby uprawiania refleksji naukowej. Klasycznie rzecz ujmując, wyróż-

3 Zob. A. Drzycimski, Kościót i świat o potrzebie dialogu, w: Parare vias Domini. Księga inspirowana działalnościa naukowa i duszpasterska księdza biskupa pelplińskiego prof. dra hab. Jana Bernarda Szlagi (1940-2012), red. K. Charamsa, W. Pytlik, Bernardinum, Pelplin 2014, s. 201-214; M. Fiałkowski, Stosunek Kościoła do świata, w: Teologia pastoralna. Teologia pastoralna fundamentalna, red. R. Kamiński, Wydawnictwo Atla 2, Lublin 2000, T. 1, s. 249-292; tenże, Zasady udziału Kościoła w rozwoju świata, RTK 4:2012, s. 53-64.

4 R. Kamiński, Tożsamość wspótczesnej teologii pastoralnej, RTK 4:2012, s. 24-25.

5 Tamże, s. 25.

6 Tamże, s. 27, zob. J. Majka, Metodologia nauk teologicznych, Wydawnictwo TUM, Wrocław 1981, s. 207-208.

7 Zob. N. Greinacher, Das Theorie-Praxis Problem in der Praktischen Theologie, w: F. Klostermann, R. Zerfass, Praktische Theologie heute, Lit Verlag, München - Mainz 1974, s. 109-110; T. Neufeld, Das Theorie-Praxis Probleme als Anfrage an die Praktische Theologie, „Franziskanische Studie” 61:1979, nr 2-3, s. 210-235. 
nia się cztery typy badań naukowych w teologii pastoralnej: monodyscyplinarne ${ }^{8}$, multidyscyplinarne ${ }^{9}$, interdyscyplinarne ${ }^{10} \mathrm{i}$ intradyscyplinarne ${ }^{11}$. W ramach teologii pastoralnej prowadzony jest dyskurs teraźniejszej sytuacji Kościoła. Wymaga on współdziałania z innymi dyscyplinami teologicznymi oraz naukami pozateologicznymi. „Należy tutaj wymienić antropologię, socjologię i psychologię religii, pedagogikę, prakseologię, teorie organizacji i zarządzania, etnologię, statystykę i socjografię itd." ${ }^{12}$ Wśród współczesnych dziedzin, które mogą współpracować z teologią pastoralną, należy wymienić również psychologię pastoralną, która może stanowić cenne źródło refleksji prowadzące do tworzenia nowych modeli duszpasterskich. Bez wątpienia obie dziedziny: teologia praktyczna i psychologia pastoralna korzystają z osiągnięć różnych dyscyplin naukowych w ramach swoich przedmiotów zainteresowań. Podejmowana współpraca służy szeroko pojętemu opisowi psychologicznych uwarunkowań działalności eklezjalnej. Celem tego artykułu jest ukazanie psychologii pastoralnej jako nauki o charakterze pomocniczym teologii praktycznej. Ukazana zostanie geneza i problematyka psychologii pastoralnej, zarysowane zostaną obszary badawcze i podstawowe zadania refleksji psychologicznopastoralnej.

Niektórzy badacze wskazują na pewien kłopot w umiejscowieniu psychologii pastoralnej w konkretnym systemie nauk ${ }^{13}$. Wynika to z faktu obecności dwóch nurtów w ramach tej dziedziny wiedzy. Pierwszy umieszcza ją w obszarze nauk psychologicznych, ze względu na typową dla psychologii metodologię badań. Drugi nurt sytuuje psychologię pastoralną w ramach teologii praktycznej. Należy zwrócić uwagę, że według tej koncepcji o umiejscowieniu psychologii pastoralnej decydują założenia antropologii teologicznej. Człowiek rozumiany jest zatem jako obraz Boga, co jest źródłem jego godności i budowania relacji do świata widzialnego i duchowego. Zdaniem Antoniego Tomkiewicza ${ }^{14}$ antropologia filozoficzna jest nieobecna we współczesnych teoriach psychologicznych. Umieszczenie psychologii pastoralnej w ramach teologii praktycznej warunkuje jej przedmiot,

8 Ten rodzaj badań charakteryzuje się wspólnym celem i metodą. Realizowany był przed rokiem 1777 i był połączeniem refleksji, reguł, rad i zaleceń odnoszących się do duszpasterskiej praktyki.

9 Badania multidyscyplinarne zakładają różne cele i różne metody. Zatem teologia pastoralna musi odnieść się do wyników badań prowadzonych przez inne dyscypliny naukowe. Nauki empiryczne dostarczają danych, które teologia pastoralna interpretuje w oparciu o teologicznopastoralny aparat naukowy.

10 W przypadku badań intradyscyplinarnych teologiczne i empiryczne metody badań łączą się w metodologiczną całość, a sama teologia pastoralna staje się „empiryczna”. Wymaga ona instrumentu naukowego, który zostanie zintegrowany w teologii np. badania z zakresu socjologii religii.

11 R. Kamiński, Tożsamość współczesnej teologii pastoralnej, dz. cyt., s. 29.

12 Tamże, s. 33.

13 A. Tomkiewicz, Psychologia pastoralna, LTP, s. 709.

14 Zob. R. Kamiński, Tomkiewicz Antoni, LTP, s. 854-855. 
tzn. sytuacja duszpasterska, która jest otwarta na obecność i działanie Boga. Oznacza to, że działalność duszpasterska nie może być zredukowana tylko do czynników psychologicznych. W psychologii wskazuje się najogólniej na dwa podstawowe obszary: psychologię teoretyczną i psychologię stosowaną. W ramach psychologii stosowanej możemy wyodrębnić właśnie psychologię pastoralną.

W XVIII i XIX wieku psychologia pastoralna uprawiana była w ramach medycyny pastoralnej oraz psychiatrii pastoralnej. Na bazie badań tych dziedzin wykładano studentom problematykę psychologicznopastoralną. Wiedza ta dotyczyła w znacznej mierze określenia stopnia poczucia odpowiedzialności człowieka chorego psychicznie za popełnione przez niego czyny. Tego rodzaju wyniki badań miały swoje odbicie w praktyce eklezjalnej, w ramach duszpasterstwa indywidualnego osób z zaburzeniami psychicznymi. Psychiatria służyła opisowi potrzeb i cech osobowości w celu zapewnienia im należytej opieki duszpasterskiej ${ }^{15}$.

Przełom wieku XIX i XX to wyodrębnienie psychologii jako samodzielnej nauki i autonomicznej dziedziny wiedzy ${ }^{16}$. Dokonało się to dzięki m.in. badaniom empirycznym Williama Jamesa w Stanach Zjednoczonych ${ }^{17}$ oraz Wilhelma Wundta w Niemczech ${ }^{18}$. Zygmunt Freud w latach dwudziestych XX wieku w świetle swojej teorii psychoanalitycznej opisał też zagadnienia związane z religijnością człowieka. Jego zdaniem religia stanowiła rodzaj iluzji, a stan człowieka nią ogarnięty był określany mianem dziecięcej nerwicy ${ }^{19}$. W związku z negatywną oceną wniosków Freuda przez teologów, dialog, jaki toczył się do tej pory między psychologią a teologią na gruncie psychologii pastoralnej, został w tamtym czasie zaniechany.

W Stanach Zjednoczonych psychologia pastoralna została zakwalifikowana jako dział psychologii badający procesy psychiczne, pojawiające się w praktyce duszpasterskiej. Ważnym wyróżnikiem tego spotkania jest otwarcie się człowieka

15 A. Tomkiewicz, Psychologia pastoralna - kierunki, zadania, metody, w: Teologia pastoralna. Teologia pastoralna fundamentalna, red. R. Kamiński, Wydawnictwo Atla 2, t. I, Lublin 2000, s. 30 .

$16 \mathrm{Na}$ Uniwersytetach Katolickich w Leuwen i Mediolanie powstały laboratoria badań z pogranicza psychologii i teologii. Jednak badania te nie znajdowały (jeszcze) przełożenia na praktykę pastoralną. W latach 70. i 80. XX w. wraz z rozwojem różnych koncepcji psychologicznych oraz psychologii opartej o liczne badania empiryczne nastąpił dynamiczny rozwój psychologii pastoralnej.

17 W Ameryce w latach pięćdziesiątych ubiegłego wieku pojawiły się inicjatywy tworzenia poradni duszpasterskich, mających na celu pomoc ludziom przeżywającym trudne sytuacje życiowe. Powstawały dwa rodzaje poradni: dla chorych przebywających w szpitalach oraz poradnie parafialne dla osób w kryzysach wywołanych codziennymi warunkami życiowymi. W 1967 r. powołano do istnienia amerykańskie Towarzystwo Psychologii Pastoralnej, które miało na celu kształcenie duszpasterzy w zakresie psychologicznego poradnictwa duszpasterskiego.

18 Od 1948 r. w Niemczech ukazuje się oficjalny miesięcznik Niemieckiego Towarzystwa Psychologii Pastoralnej.

19 J. Strojnowski, Freud Zygmund, EK 5, kol. 711. 
na obecność Boga i Jego działanie w życiu, w sytuacjach trudnych i w pogłębianiu doświadczenia religijnego. Stąd psychologowie pastoralni zajmują się głównie zasadami i technikami prowadzenia rozmów duszpasterskich, poznawaniem procesów psychologicznych na różnych etapach życia i uczestnictwa w życiu eklezjalnym, wspieraniem wierzących w różnego rodzaju kryzysach. Psychologia pastoralna jest utożsamiana z poradnictwem psychologicznym lub terapią pastoralną. Ważną rolę w rozwoju poradnictwa pastoralnego odegrali m.in. protestancki teolog Seward Hiltner ${ }^{20}$ oraz psycholog Carl Rogers ${ }^{21}$. Poradnictwo pastoralne zajmuje się wspieraniem osób na bazie antropologii chrześcijańskiej, z obecnością elementów religijnych danego wyznania. Jego zadaniem jest poprawa stanu psychicznego i pomoc w osiąganiu celu ostatecznego zbawienia.

W latach osiemdziesiątych XX wieku nastąpił dynamiczny rozwój psychologii pastoralnej ze względu na zastosowanie wielu precyzyjnych narzędzi o charakterze empirycznym, właściwych metod badawczych oraz rozwoju różnych koncepcji psychologicznych. Obecnie, próbując określić specyfikę psychologii pastoralnej, należy przyjrzeć się teoriom osobowości, na których psychologia bazuje. Klasyczny podział teorii osobowości wyróżnia: teorie psychonanlityczne (Freud ${ }^{22}$, Jung $^{23}$, Adler ${ }^{24}$, Horney ${ }^{25}$, Erikson ${ }^{26}$ ), teorie behawioralne (Watson ${ }^{27}$, Skinner ${ }^{28}$, Thorndike ${ }^{29}$, Ellis $\left.^{30}\right)$, humanistyczne $\left(\right.$ Rogers $^{31}$, Maslow ${ }^{32}$, Frank ${ }^{33}$ ) oraz analizy transakcyjnej (Berne, Golding, Harris, English).

Jeśli chodzi o kierunek psychoanalityczny, to należy zwrócić uwagę na fakt, że wspólnym elementem teorii psychoanalitycznych jest zwrócenie uwagi na wewnętrzną dynamikę człowieka, jego podświadomość. Zapomniane lub wyparte ze świadomości wcześniejsze przeżycia mogą jednak mieć wpływ na ludzkie

20 M. Kalinowski, Hiltner Seward, LTP, s. 281-282.

21 Zob. H. Pompey, Die Rezeption der Psychologie durch die Seelsorgswissenschaften im Laufe der Geschichte, „Wege zum Menschen” 1978, nr 10, s. 421.

22 J. Strojnowski, dz. cyt., kol. 711-713.

23 Z. Uchnast, Jung Carl Gustav, EK 8, kol. 249-251.

24 J. Pastuszka, Adler Alfred, EK 1, kol. 87-88.

25 M. Oleś, Horney Karen, EK 6, kol. 1229-1230.

26 Zob. L. Witkowski, Rozwój i tożsamość w cyklu życia: studium koncepcji Erika H. Eriksona, Wydawnictwo UJ, Kraków 2004.

27 Zob. J. Watson, Psychology from the Standpoint of a Behaviorist, J. B. Lippincott Company, Philadelphia - London 1919.

28 Zob. B. Skinner, Zachowanie się organizmów, Wydawnictwo PWN, Warszawa 1995.

29 Zob. E. Thorndike, Selected Writings from a Connectionist's Psychology, Greenwood Pub Group, New York1969.

30 Zob. A. Ellis, C. MacLaren, Terapia racjonalno-emotywna. Podręcznik, Wydawnictwo Helion, Gliwice 2011.

31 Zob. C. Rogers, The Clinical Treatment of the Problem Child, Houghton Mifflin, London 1939.

32 Zob. A. Maslow, Motivation and Personality, Harper \& Row, Piblishers, New York 1987.

33 Zob. V. Frankl, Człowiek w poszukiwaniu sensu, Wydawnictwo Czarna Owca, Warszawa 2013. 
myślenie i zachowanie człowieka w dorosłym życiu. Zdaniem specjalistów pomoc psychologiczna polega tutaj na odkrywaniu nieuświadomionych motywów postępowania, wygaszaniu wewnętrznych konfliktów poprzez nieskrępowaną werbalizację i analizę przeżyć, w celu doprowadzenia do ich zrozumienia i wyjaśnienia w warstwie świadomej ${ }^{34}$. Pomimo że ujęcie to jest redukcjonistyczne, może mieć pewne zastosowanie w działalności pastoralnej Kościoła, zwłaszcza w kierownictwie duchowym. Dla zrozumienia i zmiany zachowań trzeba poznać funkcjonowanie nieświadomych mechanizmów obronnych, jak: przeniesienie, projekcja, sublimacja, wyparcie itd. ${ }^{35}$ Odkrycie ich pomaga zdemaskować niedojrzałe motywy działania oraz pokazać prawdziwe motywacje danego wyboru życiowego. Jednakże warto zwrócić uwagę na fakt, że czynników nieświadomych nie można przeceniać, ważną rolę odgrywają motywy świadome.

Psychologowie nurtu behawioralnego, tacy jak John Watson, Burrhus Skinner czy Hans Eysenck, akcentują silny wpływ środowiska społecznego i warunków zewnętrznych, pomijając czynniki dziedziczne i subiektywne. „W badaniach psychologicznych przyjęto słynną zasadę, że określony bodziec (S), pochodzący ze środowiska zewnętrznego, wywołuje u człowieka określoną obserwowalną reakcję (R)"36. Zdaniem badaczy liczą się tylko badania typu obserwowalnego. Podstawą tej koncepcji jest teoria uczenia się. Zdaniem niektórych nawet reakcje wrodzone mogą być modyfikowane i wyłączone przez doświadczenie. Uczenie dokonuje się poprzez obserwację i naśladowanie „wzorca”. W procesie uczenia stosuje się wzmocnienia pozytywne i wygaszanie bodźców niepożądanych, poprzez nagrody i kary. Dużą rolę ogrywa też przystosowanie jednostki do środowiska społecznego. W duszpasterstwie chodzi często o wyuczenie określonych zachowań, o kształtowanie postaw religijnych i moralnych (cnót), a wygaszanie wad. Ograniczeniem teorii behawioralnych jest przeakcentowanie roli środowiska, przy niewielkim uwzględnianiu czynników subiektywnych i aktywności własnej.

Badacze kierunku humanistycznego (A. Maslov, C. Rogers, E. Fromm, G. Allport) zajmują się badaniem mechanizmów rozwojowo-motywacyjnych tkwiących w osobie. Akcentuje się autonomię i wolność osoby ludzkiej, zdolnej do świadomej interpretacji bodźców, decyzji i wyborów ${ }^{37}$. W człowieku istnieją pozytywne cechy, które w atmosferze miłości i zaufania można wyzwolić i rozwinąć. Środkiem w pomocy terapeutycznej jest metoda ,skoncentrowana na kliencie”, gdzie w klimacie zrozumienia, akceptacji i miłości osoba uzyskuje możliwość wglądu w siebie i dokonania w sobie pozytywnych zmian. Zarówno w duszpasterstwie jak i w psychologii humanistycznej istotne znaczenie posiada godność osoby ludzkiej i ukierunkowanie życia na wartości wyższe. Badania tego kierunku znalazły sze-

34 A. Tomkiewicz, Psychologia pastoralna - kierunki, zadania, metody, dz. cyt., s. 32.

35 Tamże, s. 33.

36 Tamże; zob. J. Watson, Behaviorism, University of Chicago Press, Chicago 1958.

37 M. Szentmártoni, Psychologia pastoralna, Wydawnictwo WAM, Kraków 1995, s. 27. 
rokie zastosowanie w prowadzeniu indywidualnego poradnictwa duszpasterskiego $^{38}$. Oprócz ewidentnych walorów tej koncepcji, do zastrzeżeń zalicza się bezgraniczną wiarę w dobroć ludzkiej natury i przeakcentowanie możliwości zmian w sobie. Ponadto psychologowie związani z nurtem humanistycznym zbyt silnie akcentują znaczenie własnego ,ja”, przy niedocenianiu znaczenia wartości obiektywnych, co jest istotne w duszpasterstwie.

Kierunek egzystencjalny ${ }^{39}$ podkreśla znaczenie sensu życia w rozwoju i terapii. Terapia dokonuje się przez pobudzanie warstw noetycznych i zastosowanie różnych technik, tj. stawianie w sytuacji ekstremalnej, gdzie pacjent musi reagować; zrobić to, czego najbardziej się boi. Doprowadzenie do konfrontacji z logosem, czyli znaczeniem własnej egzystencji, jest głównym celem logoterapii. Teoria znalazła uznanie i zastosowanie w interpretacji powołania (zwłaszcza duchownego, zakonnego) jako autotranscendencji, $w$ kierownictwie duchowym ${ }^{40}$, w duszpasterstwie chorych $^{41}$ - w zetknięciu z cierpieniem, śmiercią; w terapii uzależnień.

Analiza transakcyjna pozwala człowiekowi poznać siebie i uzyskać wgląd we własne postawy i motywacje. Dokonuje się to poprzez rozpoznanie w sobie trzech stanów osobowości (ja-dziecko, ja-dorosły, ja-rodzic oraz ich składowych) i uzyskaniu z nimi kontaktu. Pomocne jest także odkrycie i zrozumienie skryptu życiowego oraz strukturalizacji czasu (rytuały, praca, gry psychologiczne, rozrywka oraz intymność $)^{42}$. Omawiana teoria jest pomocna w kształtowaniu dojrzałej osobowości, postaw religijnych oraz w komunikacji interpersonalnej. Uczy praktycznej realizacji miłości bliźniego i samego siebie. Jej założenia bliskie są chrześcijańskiemu humanizmowi. Modele analizy transakcyjnej znajdują coraz szersze zastosowanie w katechezie, kaznodziejstwie, sprawowaniu sakramentu pojednania oraz w poradnictwie i terapii.

Żadna z zaprezentowanych teorii nie odkrywa całej prawdy o człowieku, ale każda przyczynia się do jej zrozumienia. Problemem psychologii pastoralnej (w kontekście psychologii ogólnej) jest przyjęcie właściwej antropologii. Do zrozumienia siebie człowiek potrzebuje uwzględnienia pragnień egzystencjalnych i religijnych oraz potrzeb uczestnictwa i transcendencji (pragnienie szczęścia, przynależności i akceptacji). Częste wypieranie tych pragnień i potrzeb rodzi niepokój, który ujawnia potrzebę duszpasterstwa osoby, opartego na akceptacji człowieka w duchu Bożego miłosierdzia i miłości.

Psychologia pastoralna w obecnych czasach posiada szerokie pole badawcze. Określając przedmiot badań, należy zwrócić uwagę na dwa podstawowe jej działy:

38 A. Tomkiewicz, Psychologia pastoralna - kierunki, zadania, metody, dz. cyt., s. 34.

39 Inne nazwy: analiza egzystencjalna, logoterapia, Trzecia Szkoła Wiedeńska - nazwy szkoły V. Frankla.

40 Zob. J. Misiurek, Kierownictwo duchowe, LTP, s. 374-377.

${ }_{41}$ T. Wielebski, Chorych duszpasterstwo, LTP, s. 143-147.

42 Zob. A. Tomkiewicz, Psychologia pastoralna - kierunki, zadania, metody, dz. cyt., s. 34. 
psychologia pastoralna ogólna, nazywana również ponadwyznaniową oraz psychologia pastoralna szczegółowa, określana jako wyznaniowa. Pierwsza łączy się ściśle z psychologią religii. Głównym jej zadaniem jest „,podanie sposobu rozumienia i wyjaśniania: obrazu Boga, obrazu człowieka, Kościoła jako wspólnoty osób wierzących ${ }^{43}$. W drugim z wymienionych przypadków psychologia będzie nabierała charakteru wyznaniowego, ponieważ praca duszpasterska posiada swoją specyfikę w poszczególnych wyznaniach i wspólnotach kościelnych ${ }^{44}$.

Metodologia psychologii pastoralnej jest dosyć złożona. Jako że jest to nauka o charakterze interdyscyplinarnym, łączy nauki przyrodnicze, humanistyczne oraz teologiczne. Zdaniem niektórych badaczy metodologia psychologii pastoralnej jest zbliżona do metodologii pedagogiki ${ }^{45}$. Przedmiotem materialnym psychologii pastoralnej jest wieloaspektowy i integralny rozwój człowieka. Dojrzała osobowość chrześcijanina staje się celem i formą oceny procesu formacyjnego. Chodzi o precyzyjne określenie czy taki proces przebiega prawidłowo, a jeżeli nie, to w jakich jego elementach obserwowane są pewne odchylenia oraz jaki mają charakter ${ }^{46}$. Przedmiotem formalnym omawianej dziedziny jest dojrzała osobowość człowieka, który żyje w określonej społeczności wierzących oraz jego uformowana odpowiedzialnie religijnośćc ${ }^{47}$.

II Sobór Watykański wskazał na psychologię pastoralną, jako na ważną dziedzinę wiedzy, pomagającą zrozumieć mechanizmy ludzkiego funkcjonowania. „Zachęca się teologów, żeby przy zachowaniu metod i wymogów właściwych nauce teologicznej, wciąż szukali coraz to bardziej odpowiedniego sposobu podawania doktryny ludziom sobie współczesnym; bo czym innym jest sam depozyt wiary, czyli jej prawdy, a czym innym sposób ich wyrażania, przy zachowaniu jednak tego samego sensu i znaczenia. W duszpasterstwie należy uznawać i stosować w dostatecznej mierze nie tylko zasady teologiczne, lecz także zdobycze nauk świeckich, zwłaszcza psychologii i socjologii, tak żeby również i wiernych prowadzić do rzetelniejszego i dojrzalszego życia wiary"48.

Na gruncie polskim znawcą badań o charakterze psychologicznopastorlanym jest ksiądz dr Antoni Tomkiewicz ${ }^{49}$, wieloletni pracownik Wydziału Teologii Katolickiego Uniwersytetu Lubelskiego Jana Pawła II. Jest on znawcą koncepcji niemieckiej. W swojej naukowej aktywności podejmował próby opracowania koncepcji psychologii pastoralnej. Inne ważne publikacje w języku polskim

43 Tenże, Psychologia pastoralna, LTP, s. 39.

44 J. Scharfenberg, Einführung in die Pastoralpsychologie, Vandenhoeck \& Ruprecht, Göttingen 1985, s. 23.

45 M. Dieterich, Handbuch: Psychologie und Seelsorge, Brockhaus, Züruch, s. 18-19.

46 A. Tomkiewicz, Psychologia pastoralna - kierunki, zadania, metody, dz. cyt., s. 42.

47 Tamże.

48 KDK 62.

49 Zob. R. Kamiński, Tomkiewicz Antoni, LTP, s. 854-855. 
stanowią raczej próbę zastosowania wybranych zagadnień psychologicznych do potrzeb pastoralnych, np. prace Zdzisława Chlewińskiego ${ }^{50}$, Zenomeny Płużek ${ }^{51}$, czy tłumaczona na język polski pozycja węgierskiego jezuity Mihály’ego Szentmártoniego ${ }^{52}$.

Psychologia pastoralna jako nauka pomocnicza stanowi ważną i ciekawą dyscyplinę, która wnosi określony wkład wiedzy, służący do formułowania postulatów pastoralnych. Duszpasterstwo, poszukując adekwatnych do danego czasu modeli duszpasterskich, korzysta z dorobku teologii pastoralnej oraz dziedzin pomocniczych, jak psychologia pastoralna. Wielość sposobów uprawiania psychologii sprawia jednak, że dokonanie całościowej analizy szeroko rozumianej kondycji współczesnego człowieka jest możliwe tylko przy zachowaniu metodologicznej dyscypliny. Chodzi o to, aby teologia pastoralna nie wchodziła na grunt psychologii pastoralnej i odwrotnie. Ma to swoje praktyczne przełożenie w codziennym życiu, polegające na tym, że duszpasterz nieposiadający kompetencji psychologa, nie powinien tego rodzaju pomocy świadczyć np. w ramach duszpasterstwa indywidualnego. Mając wiedzę z podstaw psychologii pastoralnej może danej osobie polecić kontakt z psychologiem. Sama zaś wiedza np. o interakcjach w małych grupach religijnych, którym duszpasterz przewodzi, może pomóc w uniknięciu wielu trudności, które mają podłoże psychologiczne, np. syndrom myślenia grupowego ${ }^{53}$.

\section{Bibliografia}

Bazylak J., Siek S., Elementy higieny psychicznej w psychologii pastoralnej, ATK, Warszawa 1983.

Cencini A., Manenti A., Psychologia a formacja, Wydawnictwo WAM, Kraków 2002.

Chaim W., Psychoanalityczne ujęcie charakterologicznych uwarunkowań stuchania stowa Bożego, w: Stuchacz słowa, red. W. Przyczyna, Poligrafia Salezjańska, Kraków 1998, s. 144-162.

Clendenen A., Martin T. W., Uzdrawiajaca siła przebaczenia, Wydawnictwo WAM, Kraków 2004.

Collins G.R., Poradnictwo chrześcijańskie, Wydawnictwo Chrześcijański Instytut Biblijny, Warszawa 2005.

50 Zob. Wybrane zagadnienia z psychologii pastoralnej, red. Z. Chlewiński, Wydawnictwo KUL, Lublin 1989.

51 Z. Płużek, Psychologia pastoralna, Wydawnictwo Instytut Teologiczny Księży Misjonarzy, Kraków 2002.

52 M. Szentmārtoni, dz. cyt.

53 W. Śmigiel, Syndrom myślenia grupowego jako zagrożenie dla funkcjonowania grup kościelnych, „Teologia Praktyczna”, t. 10, 2009, s. 85-93. 
Czaja A., Traktat o Kościele, w: Dogmatyka, Traktat o Maryi, Traktat o Kościele, red. E. Adamiak, A. Czaja, J. Majewski, Wydawnictwo Więź, Warszawa 2006, t. 2, s. 407-408.

Czy dzisiaj można formować bez psychologii?, red. M. Kożuch, J. Poznański, Wydawnictwo WAM, Kraków 2002.

Dieterich M., Handbuch: Psychologie und Seelsorge, Brockhaus, Züruch 2000.

Drzycimski A., Kościót i świat o potrzebie dialogu, w: Parare vias Domini, Księga inspirowana dziatalnościa naukowa i duszpasterska księdza biskupa pelplińskiego prof. dra hab. Jana Bernarda Szlagi (1940-2012), red. K. Charamsa, W. Pytlik, Bernardinum, Pelplin 2014, s. 201-214.

Ellis A., MacLaren C., Terapia racjonalno-emotywna. Podręcznik, Wydawnictwo Helion, Gliwice 2011.

Fiałkowski M., Stosunek Kościoła do świata, w: Teologia pastoralna. Teologia pastoralna fundamentalna, red. R. Kamiński, Wydawnictwo Atla 2, Lublin 2000, t. 1, s. 249-292.

Fiałkowski M., Zasady udziału Kościoła w rozwoju świata, RTK 4:2012, s. 53-64.

Frankl V., Człowiek w poszukiwaniu sensu, Wydawnictwo Czarna Owca, Warszawa 2013.

Greinacher N., Das Theorie-Praxis Problem in der Praktischen Theologie, w: F. Klostermann, R. Zerfass, Praktische Theologie heute, Lit Verlag, München Mainz 1974 s. 109-110.

Jaworski R., Poradnictwo pastoralne dla neurotyków, w: Leksykon teologii pastoralnej, red. R. Kamiński, W. Przygoda, M. Fiałkowski, TN KUL, Lublin 2006, s. 649-651.

Jaworski R., Poradnictwo pastoralne dla osób z zaburzona osobowościa, w: Leksykon teologii pastoralnej, red. R. Kamiński, W. Przygoda, M. Fiałkowski, TN KUL, Lublin 2006, s. 652-653.

Jaworski R., Poradnictwo pastoralne dla psychotyków, w: Leksykon teologii pastoralnej, red. R. Kamiński, W. Przygoda, M. Fiałkowski, TN KUL, Lublin 2006, s. 653-656.

Kalinowski M., Hiltner Seward, w: Leksykon teologii pastoralnej, red. R. Kamiński, W. Przygoda, M. Fiałkowski, TN KUL, Lublin 2006, s. 281-282.

Kamiński R., Problemy dyskutowane w teologii pastoralnej, „Roczniki Teologiczne", t. 48, 2001, z. 6, s. 5-18.

Kamiński R., Tomkiewicz A., Rozmowa duszpasterska i jej uwarunkowania psychologiczne, „Roczniki Teologiczno-Katechetyczne”, 33: 1986 z. 6, s. 117-134.

Kamiński R., Tomkiewicz Antoni, w: Leksykon teologii pastoralnej, red. R. Kamiński, W. Przygoda, M. Fiałkowski, TN KUL, Lublin 2006, s. 854-855.

Kamiński R., Tożsamość wspótczesnej teologii pastoralnej, RTK 4:2012, s. $24-25$. 
Kasper W., Sakrament jedności. Eucharystia i Kościół, tłum. R. Zajączkowski, Wydawnictwo Jedność, Kielce 2005.

Kehoe N., Zmagania z wewnętrznym aniołem. Wiara, choroba psychiczna, uzdrowienie, Wydawnictwo WAM, Kraków 2011.

Kroplewski Z., Kryzysy kapłańskie. Analizy psychologiczno-formacyjne, Wydawnictwo WAM, Kraków 2010.

Kroplewski Z., Sztuka rozmawiania. Poradnik dla księży, Wydawnictwo WAM, Kraków 2006.

Krzysteczko H., Poradnictwo duszpasterskie, Teoria i praktyka rogeriańskiego kontaktu pomocnego, Wydawnictwo „Powiernik Rodzin”, Katowice 1999.

Majka J., Metodologia nauk teologicznych, Wydawnictwo TUM, Wrocław 1981.

Maslow A., Motivation and Personality, Harper \& Row, Publishers, New York 1987.

Misiurek J., Kierownictwo duchowe, w: Leksykon teologii pastoralnej, red. R. Kamiński, W. Przygoda, M. Fiałkowski, TN KUL, Lublin 2006, s. 374-377.

Neufeld T., Das Theorie-Praxis Probleme als Anfrage an die Praktische Theologie, „Franziskanische Studie” 61:1979, nr 2-3, s. 210-235.

Oleś M., Horney Karen, EK 6, kol. 1229-1230.

Pastuszka J., Adler Alfred, EK 1, kol. 87-88.

Płużek Z., Psychologia pastoralna, Wydawnictwo Instytut Teologiczny Księży Misjonarzy, Kraków 2002.

Pompey H., Die Rezeption der Psychologie durch die Seelsorgswissenschaften im Laufe der Geschichte, „Wege zum Menschen” 1978, nr 10, s. 421.

Rogers C., The Clinical Treatment of the Problem Child, Houghton Mifflin, London 1939.

Scharfenberg J., Einführung in die Pastoralpsychologie, Vandenhoeck \& Ruprecht, Göttingen 1985.

Skinner B., Zachowanie się organizmów, Wydawnictwo PWN, Warszawa 1995.

Soiński J. B., Pastoralne aspekty dynamiki grupowej, ,,Teologia Praktyczna”, t. 4, 2003, s. 93-114.

Soiński J., Psychologicznopastoralne aspekty dużych zbiorowości. Zgromadzenia agoralne, ,Teologia Praktyczna”, t. 5, 2004, s. 7-23.

Strojnowski J., Freud Zygmund, EK 5, kol. 711.

Śmigiel W., Syndrom myślenia grupowego jako zagrożenie dla funkcjonowania grup kościelnych, ,Teologia Praktyczna”, t. 10, 2009, s 85-93.

Szentmártoni M., Psychologia pastoralna, Wydawnictwo WAM, Kraków 1995.

Thorndike E., Selected Writings from a Connectionist's Psychology, Greenwood Pub Group, New York 1969. 
Tomkiewicz A., Psychologia pastoralna - kierunki, zadania, metody, w: Teologia pastoralna. Teologia pastoralna fundamentalna, red. R. Kamiński Wydawnictwo Atla 2, Lublin 2000, t. 1, s. 30.

Tomkiewicz A., Psychologia pastoralna, w: Leksykon teologii pastoralnej, red. R. Kamiński, W. Przygoda, M. Fiałkowski, TN KUL, Lublin 2006, s. 709-713.

Uchnast Z., Jung Carl Gustav, EK 8, kol. 249-251.

Watson J., Behaviorism, University of Chicago Press, Chicago 1958.

Watson J., Psychology from the Standpoint of a Behaviorist, J.B. Lippincott Company, Philadelphia - London 1919.

Wielebski T., Chorych duszpasterstwo, w: Leksykon teologii pastoralnej, red. R. Kamiński, W. Przygoda, M. Fiałkowski, TN KUL, Lublin 2006, s. 143-147.

Witkowski L., Rozwój i tożsamość w cyklu życia: studium koncepcji Erika H. Eriksona, Wydawnictwo UJ, Kraków 2004.

Wybrane zagadnienia z psychologii pastoralnej, red. Z. Chlewiński, Wydawnictwo KUL, Lublin 1989.

\section{Streszczenie}

Psychologia pastoralna jest dziedziną wiedzy, która wspomaga teologię pastoralną w opisie uwarunkowań, w jakich żyje współczesny człowiek oraz mechanizmów, jakie mogą determinować jego działania i podejmowane życiowe wybory. Szczególnie ważne we współpracy tych dwóch dyscyplin są wnioski dla realizacji duszpasterstwa indywidualnego, kierownictwa duchowego oraz prowadzenia małych grup religijnych. Aby opisana współpraca mogła przynosić wymierne owoce, potrzeba metodologicznej poprawności w uprawianiu obu dyscyplin oraz realizowania takiego duszpasterstwa, które nie będzie sobie rościło praw do prowadzenia jakiejkolwiek terapii.

Slowa klucze: teologia pastoralna, psychologia pastoralna, duszpasterstwo, rozmowa duszpasterska, koncepcje psychologiczne w duszpasterstwie

Pastoral Psychology as an Auxiliary Science of Practical Theology

\section{Summary}

Pastoral Psychology is a discipline which aids Pastoral Theology with understanding the mechanisms that influence contemporary man's actions and life choices. The interdisciplinary approach can bear especially good fruits in the field of individual pastoral ministry as well as in leading small communities. One requirement of such an integrated collaboration of both theological disciplines is 
the methodological correctness. In such a way we can avoid the danger of confusing the pastoral work with a kind of psychological therapy.

Keywords: Pastoral Theology, Pastoral Psychology, pastoral ministry, pastoral counselling, psychological concepts in the pastoral ministry 